DOI: 10.20472/IAC.2017.031.045

\title{
EKATERINA SEMERIKOVA
}

Moscow School of Management SKOLKOVO, Russian Federation

\section{FACTORS ATTRACTING BANKING INVESTMENT INTO FINTECH START-UPS: RUSSIAN CONTEXT}

\begin{abstract}
:
One of the main problems for any start-up is to find funds for the idea development, product/service creation and promoting it in the market (Binks \& Ennew, 1996). In Russia banks form the main demand for fintech products and services. However, there is a belief that Russian fintech ecosystem is not well developed. This research aims at exploring which barriers for fintech start-up ecosystem development are present in Russia as well as necessary and sufficient conditions for a fintech start-up to attract bank as an investor in the context of Russian experience. Qualitative interviews with experts of Russian financial industry, including representatives from banks, a regulatory institute, IT corporations $(n=32)$ as well as quantitative survey of fintech start-ups $(n=37)$ provide data for this research. This study uses crisp set Qualitative Comparative Analysis (csQCA) to examine the presence of complex causality relationships between factors describing fintech start-up and receiving investment from banks.

Major findings of this research corroborate the belief that Russian fintech start-up ecosystem is weakly developed. The one reason for that is the gap between what fintech start-ups offer and what market actually needs. Necessary condition for receiving bank's investments according to crisp set QCA is having a business plan. Other conditions this research explores are sufficient and include: having a core competence in market and consumer understanding, income source as a commission per transaction, payments-related start-up's products or services, not aiming at owning the business while doing start-up project and also readiness of the product or service. The sufficient conditions might be absent or present in certain configurations. Finally, in Russia banks finding start-up offerings unsatisfactory choose not to invest in them or to create incubators but rather develop fintech internally.

This research contributes to the literature on QCA (Ragin et al., 2006; Skaaning, 2007), as well as financial technologies (Shim \& Shin, 2016) and develops knowledge on fintech start-ups in particular.
\end{abstract}

\section{Keywords:}

fintech, start-ups, financial services

JEL Classification: G29 